\title{
COBBETT'S TWO-PENNY TRASH
}

\section{BY PATRICIA A. UTTRACHI}

Mrs. Uttrachi is a graduate student in history at Rutgers University

$7 \mathrm{HE}$ year I 830 marked a critical turning point in the English movement for parliamentary reform. The unlamented death

1 of George IV made it necessary to call a new general election. Political reform became a party issue, with the Whig support of moderate parliamentary reform. The election campaign was fought against a background of growing discontent with Tory policies, as well as poor economic conditions. The outcome of the election was significant. Although not securing a majority, the Whigs gained thirty additional seats in constituencies where the voting was relatively fair and open, which marked an important shift in the nature of the House of Commons. In the vanguard of the reform agitation outside of Parliament was the veteran political journalist William Cobbett. ${ }^{1}$

Cobbett, who had long been an ardent advocate of radical political reform, was deeply disturbed by the uprisings in the country, especially the agricultural laborers' revolt in the summer of I830. A revolution seemed imminent. Many had come to believe, with Cobbett, that the only possible way of averting a revolution was a reform of Parliament. Cobbett devoted all his energies in 1830 to this one goal. He travelled throughout the country making scores of speeches urging the necessity of reform. Two-Penny Trash was an important instrument of this new drive for reform by Cobbett. It was a periodical published from July i 830 to July I 832 , designed to attract a far greater audience than he could reach personally.

This leading spokesman for political reform was born in 1763 in Farnham, Surrey, a market town for the farmers of the area. His father was a small farmer and proprietor of the "Jolly Farmer" tavern. All that Cobbett could boast of his birth was that he was born in Old England. This was a point of profound significance for the future author of Two-Penny Trash; his origins in the tranquil countryside affected everything he wrote. Rural life afforded little oppor-

${ }^{1}$ For discussions of Cobbett's life and work see G.D.H. Cole The Life of William Cobbett (London, 1947), and John W. Osborne, William Cobbett: His Thought and His Times (New Brunswick, r966). 


\title{
COBBETT'S
}

\section{TWO-PEN NY TRASH;}

OR,

\author{
POLITICS FOR THE POOR.
}

VOLUME: I.

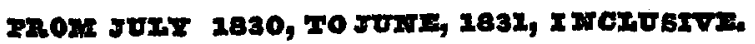

\section{LONDON :}

PRINTED BY THE AUThOR, AND SOLD AT NO. 11, BOLT-COURT, FLEETSTREET, AND MAY BE HAD OF ALL BOOKSELLERS.

1831.

Actual Size $4^{\prime \prime} \times 7^{\prime \prime}$ 
tunity for a formal education. Cobbett mastered through his own self efforts and determination the skills of reading and writing and rose to be one of the greatest, as well as most prolific, journalist in English history.

After twenty years Cobbett left the farm but he was never to forget it. Sorrowfully, Cobbett realized that the Old England of his youth was dying. A new way of life based on industry and commerce was challenging the traditional value structure in society. Cobbett's strong desire to restore Old England was the major motivating force in his drive for political reform. He supported the very radical position of universal manhood suffrage as the only way to achieve this restoration. He sincerely believed that if every man had had the right to vote then many of the injustices and evils in society, which TwoPenny Trash dramatically portrays, would never have arisen. Cobbett had a simple faith in the goodness and rationality of the common man and Two-Penny Trash was a direct product of this faith.

Two-Penny Trash was reminiscent of the edition of Cobbett's famous Political Register ${ }^{2}$ which in 1816 he began to publish for $2 \mathrm{~d}$. Prior to 1816 the issue of reform was never viewed with any sense of urgency except by a handful of radicals. But when peace finally came to England in 1815 and prosperity did not soon follow, people began to look for other causes closer to home. No longer could the war be held accountable for unfavorable economic conditions. The issue of reform gained new support from the working classes, very few of whom could vote for representatives to the unreformed House of Commons. Cobbett was one of the first to realize the importance of popular opinion in support of the reform movement. However, the high initial price of his Political Register (Is $1 / 2 \mathrm{~d}$ ) limited greatly his influence among the poor. In November I 8 I6, Cobbett, for the first time, made a direct appeal to the common people. The great reception of this address convinced Cobbett to produce along with the Register a cheaper and more compact edition for the workers. The new edition contained no news, was devoted entirely to the cause of reform and cost two pence. As a result of this new approach Cobbett's prestige among the urban workers rose. Circula-

${ }^{2}$ Two-Penny Trash has been almost totally neglected by historians because it has been overshadowed by the eighty-nine volumes of Cobbett's Political Register which he published weekly for over thirty years. Special Collections Department of the university library has one complete bound edition of Vols. I and 2 and a bound edition of Vol. 1 of Two-Penny Trash. 
tion figures multiplied from 2000 or 3000 a week to 60,000 or 70,000. ${ }^{3}$ But Cobbett's success was short lived.

The Government in the wake of the horrors of the French Revolution overreacted to a few minor disturbances within the country. A series of repressive acts of parliament directed in part at the press marked this period. The Government viewed the press as instigators in the disturbances. The suspension of the Habeas Corpus Act in March 1817 forced Cobbett to flee to America in order to escape certain imprisonment. As a result his effectiveness as a political journalist was dramatically curtailed.

On returning to England in I 819, Cobbett was confronted with further restrictive legislation, the infamous Six Acts. One of these acts was directed specifically at limiting the influence of the press. It applied the $4 \mathrm{~d}$ newspaper tax to all periodicals that appeared more frequently than every twenty-six days and sold for less than $6 \mathrm{~d}$. Cobbett was forced to raise the price of his Political Register and thus insured further restriction of his influence.

Cobbett brought Two-Penny Trash back to life again in I830 when reform agitation gained the new sense of urgency. Tro-Penny Trash could be published as a legal unstamped pamphlet, but it could only be published monthly. The title Two-Penny Trash was taken from the abusive title that Cobbett's opponents bestowed on his cheap Political Register of I8I6. But could Two-Penny Trash in 1830 reproduce the great though temporary success of Cobbett's earlier reform campaign of i 816 ?

The answer to this question involves an assessment of Cobbett's philosophy and tactics in Two-Penny Trash and the audience he sought to reach. In Two-Penny Trash, one finds in essence the political and economic thought of Cobbett which he developed in the early I 800's and maintained until his death in 1835 . Cobbett has often been referred to as a leading radical of the early nineteenth century but after reading Two-Penny Trash one recognizes that Cobbett's philosophy was conservative. Cobbett believed strongly in a society founded on landed values. The only way a man could find true meaning in life was to work the soil and Cobbett recommended that every man have a farm no matter how small it might be.

${ }^{3}$ Cobbett's Two-Penny Trash (7/1/30), p. 2. Richard D. Altick, The English Common Reader (Chicago, I 957 ), stated the circulation figures as 40,000 or 50,000 and perhaps as high as seventy thousand, p. 325 . 
A fundamental point in Cobbett's philosophy, recorded in TrooPenny Trash, was his vision of a past Golden Age of England. He believed that England was once "the happiest country in the world; ... the country of roast beef; it was distinguished above all other nations for its good food, good raiment, and good morals of its people, and it is now as much distinguished for the contrary of all of them." As part of Cobbett's traditionalist viewpoint was his support of a social structure based on class distinctions. Cobbett objected to all the socialist and equalitarian programs. He maintained that "a man should keep to himself, should call his own, should be able to apply to his own use solely, that which he had got by his labor." A man's duty was to labor in some way or another in order to raise his own means of living. He accepted the fact that "such is the nature of things, such is the order of the world that there have always been and always must be some very rich and some very poor." ${ }^{5}$

At times the tone of Cobbett's writing in Troo-Penny Trash appears bitterly class conscious; for example, Cobbett spoke often of the common people's loss of position in society. The laborer had been reduced "to a state and manner of living beneath those of hounds and pointers." ${ }^{\circ} \mathrm{He}$ complained that the laborers of England were no longer referred to as "THE PEOPLE, the COMMONS OF ENGLAND but are now called the peasantry, the population, the lower orders." " But to argue that this is proof of a growing working class consciousness developed by Cobbett, as some historians have done, is to misread him. The enemy for Cobbett was not a particular class in society but rather a way of living. The enemy in society was the "idler" who lives on the fruits of the laborer. Cobbett had an extensive list of "idlers," and among the most important offenders were the sinecurists, the pensioners, and the placemen. ${ }^{8}$

Cobbett was never a great theorist. His writing was a product more of prejudices and impulses rather than systematic thought. Cobbett was rather a master of invective and sarcasm. His pen served him best in exposing scandals and attacking his opponents. His chief target was the government. He devoted his life to examining and exposing the weaknesses of the "THING." Some of the more impressive statements in Two-Penny Trash were Cobbett's attacks on

4 Two-Penny Trash ( $7 / 1 / 30)$, p. I.

5 Two-Penny Trash $(2 / 1 / 31)$, pp. 188-189.

6 Two-Penny Trash $(\mathrm{I} / \mathrm{I} / 32)$, p. I49. ${ }^{7}$ Two-Penny Trash $(9 / 1 / 3 \mathrm{I})$, p. 5 I.

${ }^{8}$ Two-Penny Trash $(5 / 1 / 32)$, p. 23 1. 
the tax structure. Cobbett exclaimed that the "object of this work (Two-Penny Trash) is to explain to the people HOW IT IS THAT THEY ARE MADE POOR ... in other words to show what are the immediate causes of a state of things so unnatural, so contrary to what reason and nature seem to proscribe with voice irresistible. This immediate cause is ENORMOUS TAXATION."

Cobbett claimed that thirty-seven years before the taxes amounted to fifteen million pounds a year and now they were up to sixty million pounds a year. ${ }^{10}$ Half of these taxes were required to pay the interest on the National Debt which brought about this parasitic government. Cobbett's greatest objection was that the bulk of these taxes were borne by the middle and working classes; for example, the Custom and Excise taxes alone amounted to $f_{44}, 000,000$. The middle and working classes had to pay five times as much as the higher classes in proportion to their means. ${ }^{11}$ Cobbett believed that "exactly in proportion to the increase of taxes [was] the increase of poverty and misery. ..."

Cobbett's major weakness was his persistent oversimplification of social problems. He refused all other theories and solutions; for example, he rejected the Malthusian position that poverty was the product of early marriages and excessive fertility. In his play Surplus Population, which appeared in the June I 83 I edition of Two-Penny Trash, Cobbett argued that "labourers never can breed too fast because they create food and clothing and other necessaries in proportion to their numbers because, indeed, subsistence must precede the population." The real foundation of the surplus population was instead the "idlers" in society. ${ }^{13}$

Cobbett rejected also the government's program for emigration which was designed to alleviate the problem of unemployment. Cobbett felt that this plan took away the real producers in society and left the non-producers, the parasites. The real cause of the misery was taxes and the only way to alleviate the burden was a reform of parliament.

After ministers of state, ministers of religion were the most frequent target of Cobbett's wrath in Two-Penny Trash. Cobbett demanded complete abolition of the tithes and disestablishment of the

${ }^{9}$ Two-Penny Trash $(7 / 1 / 30)$, p. I 3.

11 Two-Penny Trash (7/1/30), p. 27.

${ }^{13}$ Two-Penny Trash $(7 / 1 / 31)$, p. 8.
10 Two-Penny Trash $(7 / 1 / 30)$, p. I6.

12 Two-Penny Trash $(\mathrm{I} 2 / \mathrm{I} / 3 \mathrm{I})$, p. I4I. 
Church of England. These measures would "take property from a great number of persons, it would make low who are now high, it would compel to labour for their bread many who do nothing and yet live in luxury." Cobbett insisted again that "it is, after all, the labouring-people who suffer most from the tithes, and who, in fact, pay the whole of them in the end."14 Yet they received nothing in return.

For Cobbett, politics was only a means to an end. ${ }^{15} \mathrm{He}$ never proposed a specific plan for government in Two-Penny Trash. In fact he expressed very little faith in government. He believed that political parties were a "mere sham intended to keep the people quiet while each party plunders them alternatively." "The main concern for Cobbett was not political but economic. The whole basis of Cobbett's philosophy can be stated in four words: "Cheap Government and Cheap Religion." ${ }^{\$ 17}$ Cobbett was able to support political reform because he honestly believed that reform would create nothing. ${ }^{18}$ It would in some undefined way restore the past Golden Age to England. It would bring back cheap government and cheap religion.

Due to the lack of data it is very difficult to determine exactly the readership of Two-Penny Trash. But a study of Two-Penny Trash indicates that its appeal was rather limited. Cobbett's intended audience followed from his traditionalist views and in turn doomed his agitation to failure. Two-Penny Trash was directed mainly at the agricultural laborer. The problems on which Two-Penny Trash focused were problems of the rural community, for example, the tithes and the game laws. Many of the practical analogies were of rural origin, for example, Cobbett's comparison of the Whig ministers to shoy-hoys (scarecrows). ${ }^{19}$ This is not to mention the repeated long digressions on the importance of Cobbett's corn, the brewing of beer and the versatility of mangel-wurzel.

Publishers in general found the rural community apathetic due in part to the bad communications. A journal that was published unstamped, such as Two-Penny Trash, could not be sent through the mail since the government stamp included the price of the postage.

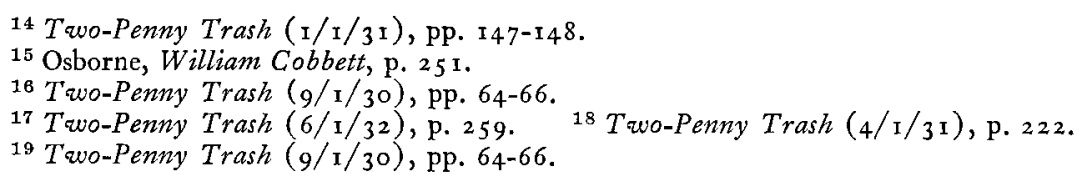


These journals and pamphlets had to find other means of circulation. This was especially difficult for the smaller regions in which demand was not large enough for a parcel to be sent to the local bookseller. ${ }^{20}$ In addition, the level of literacy was lower in the country an estimated $50 \%$ of the agricultural laborers could read as opposed to 66 to $75 \%$ in the towns. Also the habit of reading was less pervasive in the country. ${ }^{21}$

Another problem was that the majority of the rural population was apolitical. ${ }^{22}$ In Two-Penny Trash, Cobbett described the discussion of the political awareness of the agricultural community. $\mathrm{He}$ wrote that "the general notion in London has been that the country labourers are ignorant creatures, that they have no sentiment at all relative to political rights and liberties." He added that "it has been fashionable, amongst the working classes to look upon the country labourers, particularly those in the South as being totally ignorant with respect to public matters. . . ." Cobbett concluded, however, that this was never his opinion. ${ }^{23}$ But perhaps it should have been in view of the fact that Two-Penny Trash failed to attract a more potent audience. Cobbett completely ignored the new and growing urban sector of society and its special problems. By I83I twenty-five percent of the population of England and Wales lived in towns of over twenty thousand inhabitants. ${ }^{24}$ These areas played a vital role in the reform movement which culminated in the passage of the Great Reform Bill of 1832 .

There is one very important area in which Cobbett displayed a good deal of political sense and that was in reference to his support of the Reform Bill of i 832. Cobbett's decision to support the Whigintroduced bill was surprising in view of the fact that he was facing prosecution by the Whigs for seditious libel in connection with the laborers' revolt in 1830 . There was much opposition to the bill not only from the staunch conservatives and the House of Lords but also from many of the radicals, for example, Henry Hunt and Henry Hetherington, who felt that it was inadequate. Two-Penny Trash showed that the single most important issue facing the reformers

${ }^{20}$ Cole, p. 240 .

${ }^{21}$ Joel H. Wiener, The War of the Unstamped: The Movement to Repeal the British Nerwspaper Tax, $1830-1836$ (New York, 1969), p. 193.

${ }^{22}$ Patricia Hollis, The Pauper Press: $A$ Study in Working Class Radicalism of the I830's (London, 1970), p. I I I.

${ }^{23}$ Trwo-Penny Trash $(7 / 1 / 32)$, p. 266.

${ }^{24}$ John W. Osborne, The Silent Revolution (New York, I970), p. ${ }_{3} 6$. 
was the question of the suffrage. Cobbett had long supported universal male suffrage. But in the I 830 's he realized that given the state of public opinion this was out of the question. He urged his fellow reformers to accept the ten pound householder suffrage with the hope that universal male suffrage would follow. Cobbett was criticized harshly by fellow reformers who felt that he had sold out to the Whigs. In Two-Penny Trash, Cobbett defended his position well. He explained that "the suffrage was the great matter and though it fell far short of justice to the working people, I saw that by making the standard so low as the ten pound rent in the great towns, the working people would, in a few years, return from fifty to a hundred members, who would be likely to maintain their rights. I saw the injustice of shutting out the agricultural labourer. I saw but a few members, comparatively, to be returned by the working people, but then I saw that those few would be Real Men. I saw these things and on this ground and no other, I supported the Reform Bill." ${ }^{25}$

In Two-Penny Trash, Cobbett exaggerated his role in the passing of the reform bill. Cobbett stated that "indeed justice would point out an address of thanks to me, for I have done more in making reform than any other thousand men in England. . ." ${ }^{26}$ Seeing himself as the only honest man in the reform movement, he was unduly critical of the Whigs. Cobbett claimed that the whole of the Whig Ministry, with the exceptions of Lord Grey and Holland, were bitter enemies of reform. ${ }^{27}$ Cobbett compared the Whig Ministry's commitment to reform to that of a man who is compelled to marry a woman whom he has put in a family way. This man is said to be led to the church in a halter. Cobbett insisted with great exaggeration that it was he who furnished the halter and led this loving couple, the Whig Ministry and the Reform Bill, to the Church. ${ }^{28}$

Many of the causes espoused by Two-Penny Trash were soon to triumph but it is questionable whether Cobbett's efforts had much to do with it. For example, shortly after Cobbett's death, the Ecclesiastical Commission was formed, leading to many reforms within the Church. It must be concluded that Cobbett's inability or refusal to come to terms with the changing English social scene plus his view

\footnotetext{
${ }^{25}$ Two-Penny Trash (I I/I/31), p. I I7. ${ }^{26}$ Two-Penny Trash $(6 / 1 / 32)$, p. 250.

${ }^{27}$ Two-Penny Trash $(6 / 1 / 32)$, pp. 243-244.

${ }^{28}$ Trwo-Penny Trash $(5 / 1 / 31)$, p. $260(6 / 1 / 32)$, p. 246 .
} 
No. 5. Vol. II.

\section{COBBETT'S \\ TWO-PENNY TRASH}

For the Month of November, 1831.

Published monthly, sold at 12s. Od. a hutrdred, and for 300, taken at once, $11 s$.

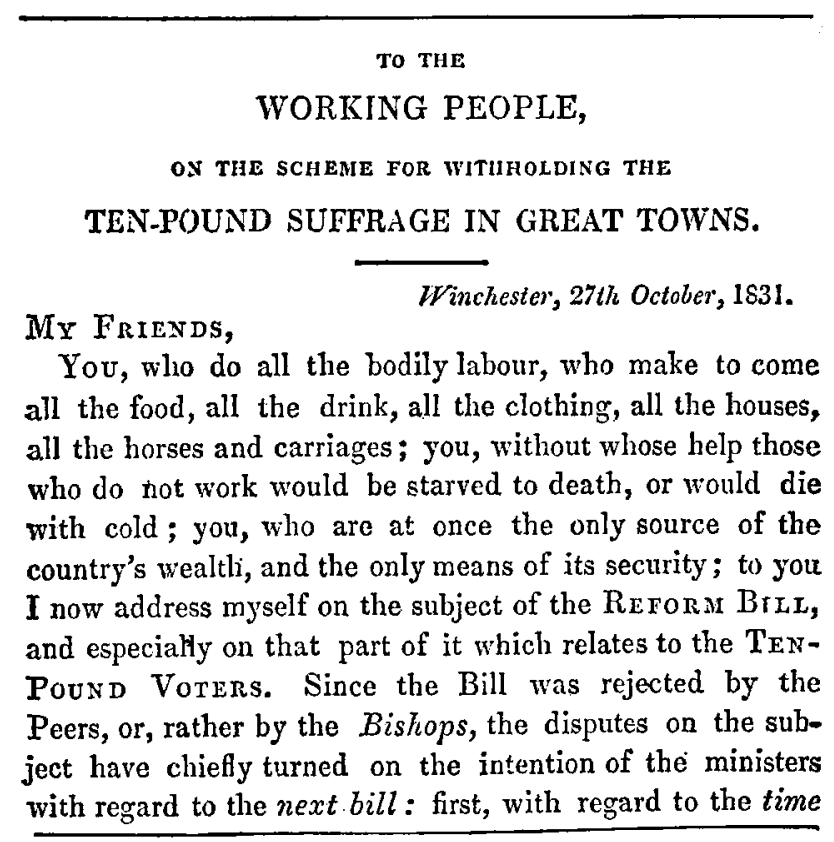

London : Published by the Author, 11, Bolt-court, Fleet-street; and sold by all Booksellers. 
of a past Golden Age were major factors in the failure of Two-Penny Trash to make a greater mark in history. Although Two-Penny Trash does not reflect adequately England in the thirties it is still valuable because it does convey in a concise and simple manner many of the political ideas of the late eighteenth and early nineteenth century: the belief that the wealth of the poor was being taken away in taxes and tithes and redistributed in favor of the idlers in society, and the conclusion that the only remedy was to reduce taxes through radical political reform.

It is true that by 1832 the message of Two-Penny Trash was becoming more and more obsolete. It was being fast outdistanced by the rhetoric of younger men, such as Henry Hetherington and James O'Brien, who were more in tune with the times. This newer rhetoric focused upon the evils of the economic process itself, industrialization, exploitation, property and power. Hetherington's Poor Man's Guardian held that the common people were distressed as did Cobbett's Two-Penny Trash. But for the Guardian the oppressors in society were the capitalists and the mere middlemen who appropriated the fruits of labor. In the new approach taxes were only a "trifling evil. ${ }^{29}$ Nevertheless much of it owed its inspiration to the older radical thinkers; for example, the new radicals' views on the population controversy, emigration and benefit societies resembled those expressed in Two-Penny Trash.

Two-Penny Trash is testimony to the lucidity and vigor of Cobbett's style which enabled him to exert his influence even into the thirties. By this time most of the other earlier radical figures had lost their effectiveness. His style was imitated by both colleagues and competitors. Part of the fascination of Cobbett lies in the fact that his journalism was so completely personal. In reading Two-Penny Trash one comes to understand not only the political philosophy of Cobbett but also the man, his personality and his joys and disappointments. One sees Cobbett in the pages of Troo-Penny Trash a kettle of prejudices, boiling over with rage at injustices, vain and egotistical. Thus Two-Penny Trash affords a splendid introduction to the political thought of the early nineteenth century and an insight to one of its most prominent figures.

${ }^{29}$ Hollis, pp. viii, 204, 225. 